\title{
СОВЕРШЕНСТВОВАНИЕ ОБЩЕПРОФИЛАКТИЧЕСКИХ МЕР ПО НЕДОПУЩЕНИЮ ПОБЕГОВ ИЗ МЕСТ ЛИШЕНИЯ СвОБОДЫ
}

\author{
Перемолотова Л.Ю.
}

\begin{abstract}
Аннотация: Основой общей профилактики побегов осужденных из мест лишения свободы является непрерывная планомерная деятельность всех структурных подразделений исправительных учреждений по выявлению и устранению причин, условий и факторов, способствующих совершению побегов. С иелью выбора наиболее оптимальных средств и методов профилактического воздействия на осужденных, а также определения стратегически важных направлений данной деятельности, необходимо осуществлять согласованные мероприятия, включающие анализ, прогнозирование, планирование, организацию и контроль в области рассматриваемого вопроса. Для достижения цели и решения задач, стоящих перед исследованием были применены общенаучные и частно-научные методы: анализ, синтез, структурно-логический метод, статистический и иные методы научного познания. при реализачии мер общей профилактики побегов из исправительных учреждений особое внимание необходимо уделять динамике качественного и количественного состава осужденных; обеспечению изолячии, надзора и охраны; размещению лии, содержамихся в исправительных учреждениях; их трудовой занятости; материально-бытовому устройству и медицинскому обеспечению. Только грамотно организованное взаимодействие сотрудников всех структурных подразделений исправительных учреждений позволит своевременно выявить причины, условия и факторы, способствующие совершению осужденными побегов.
\end{abstract}

Ключевые слова: Совершенствование, профилактика, меры, недопущение, побег, места лишения свободы, осужденные, персонал, личное дело, состояние преступности.

Профилактика побегов из исправительных учреждений - целенаправленная деятельность персонала структурных подразделений по выявлению и устранению причин, а также установлению осужденных, способных совершить эти криминальные деяния, и оказанию на них профилактического воздействия.
Основой общей профилактики побегов осужденных из мест лишения свободы является непрерывная планомерная деятельность всех структурных подразделений исправительных учреждений по выявлению и устранению причин, условий и факторов, способствующих совершению побегов. С целью выбора наибо- 
лее оптимальных средств и методов профилактического воздействия на осужденных, а также определения стратегически важных направлений данной деятельности, необходимо осуществлять согласованные мероприятия, включающие анализ, прогнозирование, планирование, организацию и контроль в области рассматриваемого вопроса.

Как показали исследования, проведенные нами в ряде исправительных учреждений уголовно-исполнительной системы, информация, которой располагают оперативные аппараты исправительных учреждений, зачастую остается невостребованной, в то время как могла бы быть использована при разработке мер профилактического воздействия. Ее анализ мог бы привести к выявлению причин и условий совершения побегов осужденными, определению ряда проблемных задач в деятельности учреждений, без решения которых невозможно осуществление мер по профилактике и предупреждению данных преступлений. Грамотная реализация имеющейся информации, правильное прогнозирование и моделирование возможности возникновения чрезвычайных ситуаций в учреждениях, своевременное планирование и организация профилактических мероприятий, а также контроль за их реализацией, должны быть направлены на достижение цели раннего упреждающего воздействия[1].

Для возможности реализации информационных ресурсов всеми сотрудниками подразделений, участвующих в профилактическом воздействии на осужденных, необходимо постоянно повышать их профессиональный уровень, проводить воспитательные мероприятия, направленные на совершенствование знаний персонала и умений применять имеющуюся информацию в практической деятельности.

Анализ статистических данных о совершаемых осужденными из исправительных учреждений побегов, показывает, что большинство побегов носят ситуативный характер, то есть, намерение совершить данное преступление возникает у осужденного, например, ввиду случайно услышанной им информации о какомлибо недостатке в организации несения службы сотрудниками на определенном участке[2]. C целью недопущения получения осужденными подобного рода сведений, способных повлиять на реализацию ими преступных намерений, необходимо оказывать воспитательное воздействие на персонал исправительных учреждений.

Для успешной организации профилактической работы по предупреждению побегов осужденных из мест лишения свободы необходимо учитывать их количественные и качественные показатели, которые отражают сведения о численности осужденных, количестве убывших из учреждения и прибывших в него, уголовно-правовую характеристику их личности[3]. Данные сведения позволяют обеспечить оптимальное распределение осужденных по отрядам и объектам работы, так как повышенная концентрация осужденных отрицательной направленности в одном месте может привести к осложнению криминогенной обстановки, и возникновению факторов, способствующих совершению побегов.

Раннее выявление у осужденных склонности к совершению преступлений и своевременная постановка таких осужденных на профилактический учет, также позволяет повысить результативность проводимых профилактических мероприятий. Для реализации данного направления деятельности необходимо внимательное изучение и анализ личных дел осужденных, их переписки с родственниками и иными лицами, наблюдение за поведением осужденных в различных ситуациях и на различных участках деятельности. Осуществлять такую деятельность должны сотрудники всех структурных подразделений исправительных учреждений: медицинские работники, сотрудники оперативных отделов, отделов безопасности и охраны, начальники отрядов, сотрудники психологической и воспитательной служб, работники производственно-технических служб, администрация учреждения[4]. Анализ имеющейся в каждом подразделении информации способствует выявлению недостатков в меди- 
цинском и материально-бытовом обеспечении осужденных, проблем во взаимоотношениях осужденных между собой и с персоналом учреждения, что может способствовать возникновению намерения совершить побег.

Основанием для постановки осужденных на профилактический учет являются наличие достоверных и проверенных сведений о намерениях совершить правонарушение или негативном влиянии на других лиц, а также медицинские и психологические показания. Сбор и подготовка необходимых материалов по постановке осужденных на профилактический учет возлагается на подразделение исправительного учреждения, являющееся инициатором постановки на профилактический учет[5].

Изучение личных дел осужденных, сбор информации, полученной сотрудниками подразделений воспитательной работы, режима, охраны, оперативного отдела, отдела специального учета, психологической лаборатории, профессионального училища, школы, предприятия, медицинской части, а также поступившей из других источников (в том числе по результатам цензуры корреспонденции), заявлений осужденных, изучение записей в Книге учета заявлений и сообщений о преступлениях, Журнале учета предложений, заявлений и жалоб осужденных, Журнале учета информации о происшествиях, Журнале учета материалов, по которым вынесены постановления об отказе в возбуждении уголовного дела, Журнале учета нарушений режима отбывания наказания и Журнале рапортов приема-сдачи дежурств и другой документации, в которой могут содержаться сведения о противоправном поведении и намерениях лиц, содержащихся в исправительных учреждениях, способствует своевременному выявлению осужденных, допускающих нарушение режима отбывания наказания и намеревающихся совершить правонарушение, в том числе побег[6].

Изучение личных дел осужденных позволяет получить информацию о наличии ранее судимостей у лица, отбывающего наказание, характере совершенного им преступления, а также способе, методах и средствах, используемых осужденным при совершении преступного деяния. Данная информация сориентирует сотрудников исправительного учреждения в правильном выборе мер профилактического воздействия на осужденного[7].

Также нельзя не учитывать поступающие в учреждение официальные информационные сводки, обзоры, справки, в которых содержится информация о состоянии преступности в стране в целом, в регионах, а также учреждениях уголовно-исполнительной системы, состоянии оперативной обстановки, происшествиях криминального характера, фактах совершения побегов, их причинах и условиях. Данная информация необходима для внедрения в деятельность учреждения положительного опыта других структурных подразделений уголовноисполнительной системы.

Ознакомление осужденных с фактами пресечения побегов и возникших последствиях в результате правомерного применения сотрудниками учреждения оружия, распространение сведений об эффективности принимаемых учреждениями и органами уголовно-исполнительной системы мер по предупреждению побегов также оказывает на осужденных общепрофилактическое воздействие. В рамках воспитательных бесед с осужденными необходимо уделять внимание их правовому образованию, предупреждению о привлечении к уголовной ответственности за совершение побега и других правонарушений[8].

В рамках реализации мер общей профилактики, направленных на недопущение побегов из исправительных учреждений, необходимо осуществлять взаимодействие не только с правоохранительными органами, но и с государственными, общественными, а также религиозными организациями, с близкими и родственниками осужденных, от которых может быть получена информация о возникновении тех или иных трудностей в процессе отбывания наказания лицом, находящимся в исправительном учреждении[9]. 
Обобщая изложенное, можно сделать вывод, что при реализации мер общей профилактики побегов из исправительных учреждений особое внимание необходимо уделять динамике качественного и количественного состава осужденных; обеспечению изоляции, надзора и охраны; размещению лиц, содержащихся в исправительных учреждениях; их трудовой занятости; материально-бытовому устройству и медицинскому обеспечению[10]. Только грамотно организованное взаимодействие сотрудников всех структурных подразделений исправительных учреждений позволит своевременно выявить причины, условия и факторы, способствующие совершению осужденными побегов, устранение которых необходимо для пресечения противоправных намерений еще на стадии умысла[11].

Для успешного достижения поставленных целей по профилактике и предупреждению побегов из мест лишения свободы необходима разработка комплексных планомерных мероприятий с привлечением всех заинтересованных сил и средств непосредственно для каждого исправительного учреждения, учитывая его территориальное расположение, укомплектованность персоналом, наполняемость, возможность привлечения осужденных к трудовой и образовательной деятельности, созданные материальнобытовые условия, а также ряд других факторов; систематическое проведение с сотрудниками исправительных учреждений занятий по изучению вопросов профилактики, предупреждения и пресечения побегов осужденных, доведение до них сводок и обзоров территориальных органов с целью изучения и внедрения положительного опыта в рассматриваемой области; внеплановое проведение общих обысковых мероприятий, осмотров территорий жилых и производственных зон в период перехода на весенне-летний период несения службы, уделяя особое внимание участкам, уязвимым в побеговом отношении; осуществление организационно-технических мероприятий по повышению надежности и устойчивости технических средств охраны и надзора.

\section{Библиография:}

1. Концепция развития уголовно-исполнительной системы Российской Федерации до 2020 года: Утв. Распоряжением Правительства РФ от 14 октября 2010 г. № 1772-р // Собрание законодательства Российской Федерации. 2010. № 43. Ст. 5544.

2. Инструкция по профилактике правонарушений среди лиц, содержащихся в учреждениях уголовно-исполнительной системы: Утв. приказом Министерства юстиции Российской Федерации от 20 мая 2013 г. № 72.

3. Правила внутреннего распорядка исправительных учреждений: Утв. приказом Министерства юстиции Российской Федерации от 3 ноября 2005 г. № 205.

4. Барабанов Н.П. Теоретические, организационные, криминологические, психологические и правовые основы предупреждения и пресечения чрезвычайных ситуаций криминального характера (побегов, захватов заложников, массовых беспорядков) в исправительных учреждениях: монография / Н. П. Барабанов, В. Н. Савардунова; Акад. ФСИН России. - Рязань, 2008. - 363 c.

5. Барабанов Н.П. Предупреждение побегов осужденных из исправительных колоний: криминологические и организационные меры: монография / Н.П. Барабанов, В.В. Попов; Акад. ФСИН России. - Рязань, 2010. - 171 с.

6. Барабанов Н.П. Меры совершенствования предупреждения побегов из исправительных учреждений и следственных изоляторов: учеб. - практ. пособие / Н.П. Барабанов, П.Н. Нестеров, В.А. Понкратов; Акад. ФСИН России, Науч. - пенитенциар. об-во. - Рязань, 2010. - 63 с. 
7. Игошин В.Г. Совершенствование деятельности по предотвращению побегов из мест лишения свободы: учеб. - метод. пособие / В.Г. Игошин, А.И. Козлов, Д.О. Шушарин; Самар. юрид. ин-т ФСИН России. - Самара, 2008. - 54 с.

8. Психологическая профилактика побегов осужденных в колониях-поселениях: метод. рекомендации / ФСИН России, Упр. соц., психол. и воспит. работы с осужденными. - М., 2008. - 19 с.

9. Пенитенциарная криминология. Учебник / под ред. Ю.М. Антоняна, А.Я. Гришко, А.П. Фильченко. Рязань: Академия ФСИН России, 2009. С. 335-338.

10. Соломатин С.В. Причины и условия, способствующие совершению побегов / С.В. Соломатин // Вестник Воронежского института ФСИН России. - 2011. № 2. С.119-123.

11. Сурин В.В. «Побеговая» активность осужденных: криминологические аспекты / В.В. Сурин, Ю.В. Шилов // Вестник Пермского института ФСИН России. - 2010. № 2. С. 23-28.

\section{References (transliterated):}

1. Kontseptsiya razvitiya ugolovno-ispolnitel'noi sistemy Rossiiskoi Federatsii do 2020 goda : Utv. Rasporyazheniem Pravitel'stva RF ot 14 oktyabrya 2010 g. № 1772-r // Sobranie zakonodatel'stva Rossiiskoi Federatsii. 2010. № 43. St. 5544.

2. Instruktsiya po profilaktike pravonarushenii sredi lits, soderzhashchikhsya v uchrezhdeniyakh ugolovnoispolnitel'noi sistemy: Utv. prikazom Ministerstva yustitsii Rossiiskoi Federatsii ot 20 maya 2013 g. № 72.

3. Pravila vnutrennego rasporyadka ispravitel'nykh uchrezhdenii : Utv. prikazom Ministerstva yustitsii Rossiiskoi Federatsii ot 3 noyabrya 2005 g. № 205.

4. Barabanov N.P. Teoreticheskie, organizatsionnye, kriminologicheskie, psikhologicheskie i pravovye osnovy preduprezhdeniya i presecheniya chrezvychainykh situatsii kriminal'nogo kharaktera (pobegov, zakhvatov zalozhnikov, massovykh besporyadkov) v ispravitel'nykh uchrezhdeniyakh: monografiya / N. P. Barabanov, V. N. Savardunova; Akad. FSIN Rossii. - Ryazan', 2008. - 363 s.

5. Barabanov N.P. Preduprezhdenie pobegov osuzhdennykh iz ispravitel'nykh kolonii: kriminologicheskie i organizatsionnye mery: monografiya / N.P. Barabanov, V.V. Popov; Akad. FSIN Rossii. - Ryazan', 2010. - $171 \mathrm{~s}$.

6. Barabanov N.P. Mery sovershenstvovaniya preduprezhdeniya pobegov iz ispravitel'nykh uchrezhdenii i sledstvennykh izolyatorov: ucheb. - prakt. posobie / N.P. Barabanov, P.N. Nesterov, V.A. Ponkratov; Akad. FSIN Rossii, Nauch. - penitentsiar. ob-vo. - Ryazan', 2010. - $63 \mathrm{~s}$.

7. Igoshin V.G. Sovershenstvovanie deyatel'nosti po predotvrashcheniyu pobegov iz mest lisheniya svobody: ucheb. - metod. posobie / V.G. Igoshin, A.I. Kozlov, D.O. Shusharin; Samar. yurid. in-t FSIN Rossii. - Samara, 2008. - 54 s.

8. Psikhologicheskaya profilaktika pobegov osuzhdennykh v koloniyakh-poseleniyakh: metod. rekomendatsii / FSIN Rossii, Upr. sots., psikhol. i vospit. raboty s osuzhdennymi. - M., 2008. - 19 s.

9. Penitentsiarnaya kriminologiya. Uchebnik / pod red. Yu.M. Antonyana, A.Ya. Grishko, A.P. Fil'chenko. Ryazan': Akademiya FSIN Rossii, 2009. S. 335-338.

10. Solomatin S.V. Prichiny i usloviya, sposobstvuyushchie soversheniyu pobegov / S.V. Solomatin // Vestnik Voronezhskogo instituta FSIN Rossii. - 2011. № 2. S.119-123.

11. Surin V.V. «Pobegovaya» aktivnost' osuzhdennykh: kriminologicheskie aspekty / V.V. Surin, Yu.V. Shilov // Vestnik Permskogo instituta FSIN Rossii. - 2010. № 2. S. 23-28. 